\title{
MACHADO DE ASSIS E A TRADIÇÃO DOS COMEDIANTES ESTOICOS ${ }^{1}$
}

\author{
Daniela Soares Portela \\ UEMG / Iel-Unicamp / CNPq \\ Frutal, MG / Campinas, SP, Brasil
}

\begin{abstract}
Resumo: Hugh Kenner (2011) considera que Flaubert seria a matriz dos escritores considerados como "comediantes estoicos", seguido por Joyce e Beckett. Esse termo definiria aqueles escritores que percebem a literatura como um sistema fechado de signos, em que as 26 letras do alfabeto e suas possibilidades comutativas, assim como os lugares adequados dos diversos atos de falas a situações específicas de comunicação, são os recursos que permitem ao escritor a criação de uma técnica que diferencia as possibilidades da comunicação escrita das práticas de oitiva. Ao seguir essa tradição, Machado de Assis desqualifica toda uma herança literária, rompe com a ilusão do projeto de totalidade da estética realista queirosiana e denuncia o aspecto arbitrário do signo linguístico e toda a matéria empírica representada por ele.
\end{abstract}

Palavras-chave: iconografia; oitiva; fragmentação; materialidade do suporte.

\section{Machado de Assis and the tradition of the Stoic comedians}

\begin{abstract}
Hugh Kenner (2011) believes that Flaubert would be the chief writer in the group of "Stoic comedians", followed by Joyce and Beckett. This term defined those writers who deemed literature to be a closed system of signs, in which the 26 letters of the alphabet and their commutative possibilities, as well as the appropriate places of different acts of speech in specific situations within communication, are the resources that enable the writer to create a technique that distinguishes the possibilities of written communication from the spoken word. Tofollowthis tradition, Machado de Assis disqualifies all the literate cultural inheritance, breaks from the illusion of the project of totality of Queirosiana's realistic aesthetics and denounces the arbitrary aspect of the linguistic sign and all the empirical matters it represents.
\end{abstract}

Keywords: iconography; spoken word; fragmentation; material culture.

A consciência da expressividade do suporte literário está tratada recorrentemente na literatura crítica machadiana e, fundamentalmente, nos cinco últimos romances para, verificar a funcionalidade do uso do capítulo curto como expressão de uma ficção que evidencia a ruptura e a fragmentação do material de

\footnotetext{
${ }^{1}$ Este artigo é parte da pesquisa de pós-doutorado financiada pela Fapesp, sob orientação de João Adolfo Hansen.
} 
representação literária. Desse modo, busca-se dissolver o projeto ideológico de unidade das artes e da ciência da segunda metade do século XIX.

Esses romances debatem os princípios da estética realista sob a perspectiva da desnaturalização cultural da relação entre realidade empírica e signo verbal. Ao propor o encurtamento dos capítulos como técnica narrativa de expressão de uma realidade fragmentada, Machado rompe com o ilusionismo da totalidade do projeto de inventário realista, bem como das propostas filosóficas do século XIX: a medicina experimental de Claude Bernard, o positivismo de Auguste Comte, a evolução de Darwin, enfim, a ideia de um tempo evolutivo e totalizante, pelo qual a história da humanidade pudesse ser explicada e controlada como num sistema de regras imutáveis e previsíveis. $^{2}$ A destruição da verossimilhança narrativa por "um morto que escreve, caso de Brás Cubas, ou um vivo desmemoriado que lembra, caso de Dom Casmurro" $^{3}$ permite a Machado encenar a inversão das convenções consideradas "verdadeiras" pelos leitores. Além disso, na relação entre os dois últimos romances, Machado propõe uma questão de veridicção: nenhuma das passagens citadas em Esaú e Jacó como partes constitutivas do Memorial de Aires podem ser encontradas no livro publicado de fato em 1908. Há, apenas, simulacro de uma mimese artística em que a referência efetuada desloca a significação do representado para outro signo.

A partir da rubrica de Brás Cubas, no prólogo da terceira edição de Memórias póstumas, Machado de Assis refuta, nos romances da fase realista, o senso comum sobre a noção de autoria. A proposta de um defunto ocupando a função da "individualidade empírica responsável, como causa criadora" do romance que o leitor tem em mãos fratura "o princípio explicativo que postula um nexo de necessidade entre efeitos de sentido e seu criador, tido como identidade prévia de uma unidade de intuição, ou de pensamento". ${ }^{4}$ Essa ruptura se torna ainda mais radical porque satiriza a ideia romântica de que a obra de arte é a expressão de uma individualidade sensível. Por outro lado, satiriza também "a morte do autor", proposta por Flaubert como dispositivo

\footnotetext{
${ }^{2}$ AUERBACH, E. Figura. Trad. Duda Machado. São Paulo: Ática, 1997.

${ }^{3}$ HANSEN, J. A. Dom Casmurro: simulacro \& alegoria. In: Machado de Assis - ensaios da crítica contemporânea. GUIDIN, M. L., GRANJA, L., RICIERI, F.W. (Orgs.). São Paulo: Editora da Unesp, 2008. p. 151

${ }^{4}$ HANSEN, J. A. Autor. In: Palavras da crítica. Org. José Luis Jobim. Rio de Janeiro: Imago, 1992. p. 11 .
} 
técnico na produção de sentido de uma aparente objetividade do texto literário. Se o efeito desse assassinato seria "não destacar as relações da obra com o autor, nem querer reconstituir através dos textos um pensamento ou uma experiência" ${ }^{5}$ para privilegiar o jogo de suas relações internas, a sátira machadiana em Memórias póstumas se torna ainda mais corrosiva, ao propor como substrato de sentido das relações internas a materialidade do texto: espaços em branco, mancha de texto, tamanho da fonte, relação entre trechos, ou seja, uma recusa da metafísica que postula existir sentido para além da materialidade do objeto. ${ }^{6}$

Em Quincas Borba, o princípio explicativo entre o criador e sua invenção também será rompido pelo esfacelamento programático da unidade do produto literário. Há, pelo menos, três obras sob a mesma rubrica: um texto publicado em folhetins, que contava com o apoio visual de seu suporte, um texto imaginado para a oitiva - principal meio de circulação da obra, responsável por $90 \%$ da recepção, como aponta texto do editorial da revista $A$ Estação $^{7}$ - e o texto publicado posteriormente em volume.

Em Dom Casmurro, a questão problematiza-se ainda mais, pois Bento Santiago não estabelece equivalência fictícia imediata com o narrador, e suposto autor da obra, Dom Casmurro, como demonstram Hansen e Suriani da Silva. ${ }^{8}$ Isso significa que o produtor da matéria narrativa que o leitor tem em mãos é um simulacro, ou seja, a entidade ficcional que projeta a experiência de Bento Santiago no romance Dom Casmurro é uma lacuna, como se autointitula o narrador. ${ }^{9} \mathrm{O}$ resultado disso, como aponta Hansen, é um texto estruturado numa espiral crescente de distorções e

\footnotetext{
${ }^{5}$ FOUCAULT, Michel. O que é um autor? In: Ditos e Escritos: Estética - literatura e pintura, música e cinema. v. III. Rio de Janeiro : Forense Universitária, 2001. p. 267.

${ }^{6}$ Machado de Assis recorrentemente satiriza a proposta metafísica de que existiria uma realidade ideal da qual a realidade material (empírica) seria apenas uma sombra. Talvez a mais exemplar imagem dessa sátira esteja no conto "O segredo do Bonzo: capítulo inédito de Fernão Dias Pinto", quando Diogo Meireles recorre ao expediente do "nariz metafísico" para convencer os cidadãos de Fuchéu a aceitarem a extração de seus narizes horrendos e inchados. (ASSIS, Machado de. Obra completa. v. 2. Rio de Janeiro: Aguilar, 1962. p. 327).

${ }^{7}$ No caso de A Estação, particularmente, os editores acreditavam que cada assinante representava, "termo médio, dez leitores, o que nos dá uma circulação de cem mil leitores, quando, aliás, nossa tiragem é apenas de dez mil assinaturas" (A Estação, 15 de março de 1882).

${ }^{8}$ HANSEN, João Adolfo. Dom Casmurro: simulacro \& alegoria, cit., p. 143-177. SILVA, Ana Claúdia Suriani da. Dom Casmurro: uma elegia moderna - Diálogo com Lord Jim, de Joseph Conrad. In: SENNA, Marta de e GUIMARÃES, Hélio de Seixas (Orgs.). Machado de Assis e o outro: diálogos possíveis. Rio de Janeiro: Móbile Editorial, 2012. p. 139-157.
}

${ }^{9}$ Dom Casmurro. Paris; Rio de Janeiro: H. Garnier Livreiro- Editor, 1889. p. 4. 
deslocamentos de discursos, inviabilizando qualquer possibilidade de interpretação em que a intenção do autor (isso inclui o "paradigma do pé atrás", como indica Baptista, 1998, sobre a leitura de Helen Caldwell, 1960) funciona como dispositivo de autorização discursiva.

De forma mais radical, ao legitimar Dom Casmurro como autor suposto do romance homônimo, Machado de Assis mobiliza, pela inversão, a relação cartesiana de causa e consequência. Se na realidade empírica a obra é a consequência da manufatura $(a r s)^{10}$ de um determinado produtor, em Dom Casmurro as lacunas de sentido produzidas pelos elementos de articulação do efeito de suspense da trama narrativa criam a imagem de um autor manipulador e desmemoriado; logo, o autor é uma lacuna cuja determinante abstrata que lhe confere existência é a forma narrativa que se apresenta como livro, supostamente atribuído a ele. Nesse sentido, o livro funciona numa relação de dependência dupla: é produto de um autor suposto que se define como "desmemoriado que lembra" e, ao mesmo tempo, define esse autor, por meio de suas lacunas, subterfúgios narrativos que não determinam para o leitor quem é Dom Casmurro. Um "desmemoriado que lembra", como indica Hansen, ${ }^{11}$ é uma contradição entre termos que resulta num vazio de significado. Outros vazios são as memórias de Dom Casmurro, projetadas como matéria de ficção na composição do romance. ${ }^{12}$ Esses vazios, tão bem representados graficamente pelos longos espaços em branco que separam os capítulos na primeira edição de 1889, conferem sentido à materialidade do objeto livro (embora as edições posteriores, possivelmente por economia, tenham suprimido esses espaços).

Não é possível acreditar que a primeira edição tenha sido obra do acaso, fundamentalmente se for considerado o fato de que o aspecto gráfico do livro determinava o público do romance e, fundamentalmente, a imagem da qualidade da

\footnotetext{
10 "Na Roma clássica, auctor é o que, tendo a posse de uma técnica (ars), exercita sua arte como artifex, segundo regras precisas e específicas de articulação (artificialis). Como artificiosus, perito, conforme um artificium, ou princípio, é também um gnarus, que não ignora a aucttoritas e por isso narra, produzindo artefatos que dão autoridade e servem de exemplos para outros." In: HANSEN, João Adolfo. Palavras da crítica, p. 18.

${ }^{11}$ HANSEN, J. A. Dom Casmurro: simulacro \& alegoria, cit.

${ }^{12}$ Sobre o processo de imitação da perda de si pela linguagem em Dom Casmurro, ver: PASSOS, J. L. Machado de Assis - o romance com pessoas. São Paulo: Edusp; Nankin, 2007. p. 174-217.
} 
obra literária. ${ }^{13}$ Que Machado sabia disso, comprova-o, de forma exemplar, uma carta datada de setembro de 1902, endereçada ao Sr. Lansac, procurador de H. Garnier no Rio de Janeiro, sobre a reedição em volume de Várias histórias proposta por Machado àquela editora, que adquirira a "propriedade inteira e perfeita", em escritura de 16 de janeiro de 1899 de Páginas recolhidas, 1899; Dom Casmurro, 1899; Quicas Borba, 1891; Memórias póstumas de Brás Cubas, 1881; Iaiá Garcia, 1878; Helena, 1876; A mão e a luva, 1874; Ressurreição,1872; Histórias sem data, 1884; Papéis avulsos, 1882; Histórias da meia noite, 1873; Contos fluminenses, 1870; Americanas, 1875; Falenas, 1870; e Crisálidas, 1864. A epístola demonstra a insatisfação do escritor carioca com o tratamento gráfico que suas Várias histórias estavam recebendo:

Comparez une page de la première avec une autre de la vôtre: la ligne de celle-ci est plus longue, et chaque page compte 38 lignes; les pages de celle-là sont formées avec 34 lignes, et vous pourrez voir la différence de longueur. [...]. Pour la vérification et la comparaison, vous trouverez ci-jointes les deux premières pages de l'édition Laemmert. Je vous prie, Monsieur Lansac, de transmettre ces considérations à Monsieur Garnier, qui en reconnaîtra la justesse, et comprendra la convenance d'ordonner quelque chose pour éviter à temps ce que je crois préjudicable à notre affaire. ${ }^{14}$

Como indica Ana Cláudia Suriani da Silva, a editora Laemmert havia lançado uma primeira edição de Várias histórias com 310 páginas. A segunda, proposta por Garnier, teria apenas 230. Por isso, Machado acreditava que uma edição menor poderia desqualificar sua obra e prejudicar as vendas.

\footnotetext{
${ }^{13} \mathrm{O}$ formato do livro não só é a materialização desse objeto para uso do público, como também o elemento distintivo da qualidade de seu autor. Gennette (GENNETTE, G. Paratextos Editoriais. Trad. Álvaro Faleiros. Cotia: Ateliê, 2009. p. 22) esclarece que "No início do século XIX, quando os grandes volumes haviam-se tornado mais raros, a diferença de importância ocorria entre os in- $8^{\circ}$ para a literatura séria e os in- $12^{\circ}$ e menores para as edições baratas reservadas à literatura popular: sabe-se que Stendhal falava com desprezo dos "pequenos romances in $12^{\circ}$ para as camareiras".

${ }^{14}$ SILVA, Ana Cláudia Suriani da. Machado de Assis's Philosopher or Dog? From serial to book form. Oxford: Legenda (Maney Publishing), 2010. p. 26. "Compare uma página da edição Laemmert com a sua edição: nesta, a linha é muito maior, e cada página tem 38 linhas; as páginas daquela têm 34 linhas, e o senhor pode ver a diferença de comprimento. Para poder verificar e comparar, o senhor vai encontrar esta carta com as duas primeiras páginas da edição Laemmert, para que possa transmitir as minhas preocupações ao Sr. Garnier. Acredito que irão reconhecer a sua relevância, e compreenderão a conveniência de propor qualquer solução que possa evitar a tempo aquilo que eu acredito ser prejudicial para o projeto do nosso livro." (Tradução livre.)
} 
Mas Machado de Assis não apenas conhecia o valor comercial da materialidade gráfica de suas obras, como também o valor estético desses espaços. A versão de Quincas Borba publicada em livro opera a tradução do tempo narrativo em espaço, na cena em que Rubião está atormentado de ciúmes por causa de uma carta que Sofia teria enviado a José Maria. A composição da cena evidencia a consciência de uma estética iconográfica mobilizada em Quincas Borba e refere-se aos capítulos 94, 95 e 96 do folhetim, publicados nas páginas 36 e 37 de 31 de maio de 1888. Esses capítulos foram reelaborados e sintetizados no capítulo 90 do livro. Entretanto, embora obedecendo a uma lógica da condensação do episódio que singulariza o ciúme doentio de Rubião por Sofia, que o leva a assassinar uma caravana de formigas que passava pelo peitoril da janela - perto da qual Rubião se vestia -, o livro perde-se em uma anedota, aparentemente sem função no contexto. Logo após o assassinato (obviamente a imagem é bastante irônica e sintetiza a pusilanimidade de Rubião), uma cigarra passa a cantar e, a Rubião, o som assemelha-se ao nome Sofia. Diagramada com espaçamentos ícones do tempo de "enunciação" da cigarra - "Sôôôô... fia, fia, fia, fia, fia, fia... Sôôôô... fia, fia, fia, fia." ${ }^{15}$, a expressão vem em fonte modificada, em itálico, e apresenta dois espaços entre cada sílaba. O folhetim termina o episódio nesta cena, mas o livro continua ainda, o mesmo capítulo 90, na página 205 (texto realçado pelo espaçamento deixado na página 204) com uma reflexão do narrador, seguida pela reflexão da cigarra, transcrita em francês e na mesma fonte da enunciação do nome de Sofia, na página anterior: "Vous marchiez? J'en suis fort aise. / Eh bien! mourez maintenant".

Ao inverter o texto de La Fontaine ("Vous chantiez? J'en suis fort aise. / Eh bien, dansez maintenant."), e aproximar essa inversão, pela expressão gráfica da escolha da fonte, ao nome de Sofia, Machado opera três dispositivos de produção de sentido do texto. Primeiro: realça, de forma irônica, a inferioridade de Rubião em relação à cigarra. Ele não dominava o francês e lia os folhetins de Feuillet com muita dificuldade, por serem contemporâneos e ainda não serem traduzidos, como atesta o capítulo 80 . Segundo, inverte a moral da fábula e cristaliza essa inversão na imagem da formiga que se ri do "Homero gaulês". Terceiro, subordina as duas relações anteriores à tradução explícita da linguagem oral para a escrita. Os dois trechos, referentes ao pensamento e

\footnotetext{
${ }^{15}$ ASSIS, Machado de. Quincas Borba. Rio de Janeiro: H. Garnier Livreiro-Editor, 1891. p. 204.
} 
ao canto da cigarra, iconizados numa fonte distintiva do restante do texto, são estilizações de um suposto discurso oral, traduzido, no registro escrito, pelo espaçamento duplo horizontal na folha em branco (no caso do nome de Sofia) ou vertical (no caso da transcrição modificada da fábula de La Fontaine). Dessa forma, Machado traduz a duração do tempo da fala em quantidade de espaço na folha em branco e mais uma vez subordina o interesse da fábula do texto ao aspecto gráfico de sua expressão. $\mathrm{O}$ atributo da substância (quantidade de dois tempos no nome de Sofia cantado pela cigarra) passa a ser a substância do caracterizado por esse atributo, pois a diagramação do espaço da folha torna-se mais significativa do que aquilo que a linguagem escrita propõe como signo verbal. Essa inversão da hierarquia, cristalizada na imagem da cigarra que se ri da fábula de La Fontaine e dessa forma desqualifica toda uma herança de cultura letrada, é um dos resultados estéticos conquistados pela estratégia de representação iconográfica em espelho da segunda fase da obra romanesca de Machado de Assis.

Essa desqualificação estética da tradição é operada de forma mais radical em Dom Casmurro. Porque o suposto autor se propõe como um desmemoriado, o resultado lógico dessa suposta "desmemória" é a substituição da história, marcada por datas e fatos exatos, pela afetação do exame de consciência de um sujeito atormentado em relação à experiência vivida.

O que interessa não é o fato em si, mas o exame do fato. Hierarquicamente, a consciência afetada de Dom Casmurro está no primeiro plano da narrativa e perversamente substitui a história narrada. Além disso, a matéria ficcional que o leitor recebe é a representação de um autor ficcional que representa sua consciência, embora essa representação, por ser infinita, seja impossível. O que se evidencia na ficção machadiana é a impossibilidade de o eu ser objeto imediato do conhecimento, porque uma alma cognoscível solicita uma segunda alma para conhecer a primeira e uma terceira para conhecer a segunda, numa espiral infinita. Ou seja, há uma fratura entre a afetação da consciência da história que Casmurro oferece e a história (material, diagramada em longos espaços em branco) que o leitor recebe.

Esse dispositivo de regressão ao infinito da imagem representada opera uma inversão da ordem temporal neste romance (já ensaiada em Memórias póstumas de Brás 
Cubas, quando a personagem Virgília é representada lendo o romance que Brás Cubas escreve): a invenção artística precede o signo que efetua a designação do inventor. No capítulo LIX, "Convivas de boa memória", Dom Casmurro representa, além da sua memória afetada como falha, a forma como ele lê um livro omisso, equivalente ao que está escrevendo. Além da metalinguagem, uma escrita continuamente autorreferida como interpretação dos próprios conceitos que cita na sua construção, o capítulo também efetua uma articulação especular, a matéria representada representa a si mesma representando. Não apenas o processo de representação torna-se material do simbólico, mas há também a ruptura com a moldura ficcional, pois o autor suposto torna-se personagem da obra e deixa de ser o signo que designa a realidade empírica (no caso uma ficcionalização da realidade empírica, visto que o autor Dom Casmurro também é uma invenção) e passa a signo designado como signo. Por isso, essa matéria não é mais a consequência de um processo, mas um tempo contínuo de autorreferenciação que rompe com a lógica temporal de causa e consequência:

E antes seja olvido que confusão; explico-me. Nada se emenda bem nos livros confusos, mas tudo se pode meter nos livros omissos. $\mathrm{Eu}$, quando leio algum desta outra casta, não me aflijo nunca. O que faço, em chegando ao fim, é cerrar os olhos e evocar todas as coisas que não achei nele. Quantas ideias finas me acodem então! [...]

É que tudo se acha fora de um livro falho, leitor amigo. Assim preencho as lacunas alheias; assim podes também preencher as minhas. ${ }^{16}$

\section{A iconografia como técnica narrativa}

O preenchimento de lacunas alheias se dá de forma exemplar em Memórias póstumas de Brás Cubas, como nos capítulos "O velho diálogo de Adão e Eva" e "De como não fui ministro d'Estado". O último, inclusive, é apresentado graficamente, na primeira edição da obra, ocupando toda a página 349, contendo o título seguido de cinco linhas pontilhadas. Na publicação seriada da Revista Brazileira, entretanto, essa diagramação era impossível, também por motivo de economia. "O velho diálogo de Adão e Eva", por exemplo, sai publicado no Tomo V, em $1^{\circ}$ de julho de 1880 , ocupando

\footnotetext{
16 Idem, p. 177.
} 
as páginas 127 (pela metade, depois do fim do capítulo LV, "A pêndula" - que no livro é o capítulo LIV -, publicado nas páginas 162,163) e 128 inteira. É lógico que a diagramação do livro valoriza muito o aspecto visual do índice sonoro de teor sexual, formalizado por uma abstração musical que substitui o signo verbal por pontos de exclamação e reticências que "nos permitem reconhecer as entoações (anticadências, cadências, suspensões), ora pressupô-las (semicadência e semi-anticadências). Ou seja, da fala das personagens, ficamos apenas com a música abstrata, isto é, a tonalidade sem a letra". ${ }^{17}$ Além desse índice, o capítulo, também é a iconização de uma imagem, composta por pontos, espaços e signos verbais que referem os nomes Virgília e Brás Cubas, dispostos nas páginas 164-165, abertas em sequência. Essa imagem performatiza um quadro, emoldurado pelas margens de $2 \mathrm{~cm}$ nos lados direito e esquerdo das páginas. Além disso, é possível supor que esse resultado tenha sido planejado por Machado de Assis. Ao contrário de Quincas Borba, em que o autor reformulou o texto, Memórias póstumas de Brás Cubas apresenta textos quase idênticos, tanto em livro como no folhetim, serializado na Revista Brazileira. Isso permite afirmar que Machado utilizou a mesma matriz de impressão, o que barateava (e muito) o custo de produção do livro. Até porque o formato da Revista Brazileira, in- $8^{\circ}$, era o mesmo do livro impresso em que as Memórias póstumas foram publicadas em primeira edição. Entretanto, o livro apresenta um capítulo a menos em relação ao folhetim, anterior às páginas do capítulo "O velho diálogo de Adão e Eva", economia de meios que pode ter sido propositalmente reformulada para permitir a diagramação apresentada na primeira edição.

Contudo a função de "O velho diálogo de Adão e Eva" abrange ainda outro aspecto. Ele funciona como uma imagem inversa ao capítulo XC, "O velho diálogo de Adão e Caim". Capítulo extenso para o padrão do livro, ocupa as páginas 250 e 251 inteiras. Repleto de enumerações equivalentes, nele Brás Cubas usa um exagero de signos para referir vários vazios: a ausência de herança do finado Viegas; ("E nada. Nenhuma lembrança testamentária, uma pastilha que fosse, com que do todo em todo não parecesse ingrato ou esquecido."), ${ }^{18}$ a ausência de diálogo entre os amantes e a

\footnotetext{
${ }^{17}$ SILVA, A. M. S. Os bárbaros submetidos - Interferências midiáticas na prosa de ficção brasileira. São Paulo: Arte e Ciência; Unimar, 2006. p. 90.

${ }^{18}$ ASSIS, Machado de. Memórias póstumas de Brás Cubas. Rio de Janeiro: Typographia Nacional, 1881. p. 250.
} 
ausência de interesse de Brás Cubas em relação a tudo que não fosse o filho que Virgília esperava: "Um filho! Um ser tirado do meu ser! Esta era a minha preocupação exclusiva daquele tempo. Olhos do mundo, zelos do marido, morte do Viegas, nada me interessava por então, nem conflitos políticos, nem revoluções, nem terremotos, nem nada". 19

Isso permite inferir que, em Dom Casmurro, a diagramação significativa de vários capítulos seja propositalmente engendrada por Machado de Assis. Na página 23, por exemplo, o autor apresenta o capítulo 8, "É tempo". Sem função na fábula narrativa, o texto funciona como uma apresentação do próximo, "A ópera". A diagramação regular da obra prescreve 17 linhas em cada página de início de capítulo e 31 linhas nas páginas subsequentes, o que equivale a dizer que, fora o título, a diagramação reservava um espaço de 10 a 11 linhas em branco em cada início de capítulo. Como o aproveitamento total da página previa 17 linhas, o capítulo 8 está emoldurado entre um espaço branco de 10 linhas e outro de 5 no final. Como o texto funciona apenas como apresentação do próximo, o espaço em branco funciona como um intensificador de expectativa, um momento de silêncio, inventado para os olhos, para valorizar a matéria narrativa do capítulo 9.

Há outras passagens exemplares, mas a fatura estética é a mesma. Se, como afirma Suriani da Silva (2010), Machado de Assis aproveita o material extensivo da revista A Estação como elemento de composição do romance Quincas Borba, é bastante provável que o autor carioca faça o mesmo em relação à extensão das manchas brancas da página em que Dom Casmurro iria circular.

Em Quincas Borba há uma relação exemplar desse aproveitamento. Na croniqueta de 15 de abril de 1888, Artur Azevedo faz um elogio à filantropia da cidade do Rio de Janeiro para socorrer o incêndio do teatro Baquet:

O grande assunto da quinzena foi o incêndio do teatro Baquet, do Porto, horrível catástrofe, idêntica à da Ópera de Paris. Já n'uma das minhas moxinifadas teatrais eu disse que nesta terra:

${ }^{19}$ Idem, p. $250-251$. 


\section{Uma coisa é ser estranho}

E outra é ser português

Portanto, não admira que à nossa população impressionasse dolorosamente aquele desastre. Abrem-se subscrições, organizam-se espetáculos, e sob qualquer pretexto fazem-se coletas em benefício das vítimas.

O brasileiro abre a sua bolsa com a mesma facilidade com que abre o seu coração. Ainda bem. ${ }^{20}$

Ironicamente, a partir de 31 de maio de 1888, Quincas Borba passa a referir a comissão filantrópica fundada por Sofia para socorrer as vítimas de uma inundação em Alagoas, mas o intuito da bela dama era o de aproximar-se da baronesa Fernanda para ascender socialmente.

Em Quincas Borba, Machado radicaliza o aproveitamento do espaço da folha como elemento significativo no processo de decodificação da leitura, ao propor a tradução do tempo da oralidade em espaços de diagramação da página em branco. Embora o processo de reescrita do romance - em que as inúmeras variações ocorridas entre a versão do folhetim para a do livro são evidentes - possa ter sido motivado por aquilo que Saraiva ${ }^{21}$ entendeu como uma espécie de consciência do público receptor de cada veículo material, ou seja, por essa percepção crítica, na transição do folhetim para o livro "Machado ajusta a narrativa a uma nova materialidade, privilegiando a concisão e o envolvimento ativo do receptor", o resultado estético dessa passagem é significativo para o projeto literário machadiano. Porque, apesar de muito diferentes, tanto Quincas Borba folhetim quanto a versão em romance levam o mesmo título e a mesma assinatura de autoria. Essa decisão editorial não pode ser ignorada. Em relação ao título, o resultado estético é um questionamento metafísico; em relação à autoria, o artefato inventivo aponta para o esfacelamento da noção de propriedade da arte burguesa. Desta forma, a percepção machadiana de arte se opõe à originalidade e à organicidade românticas da arte burguesas. Da mesma forma que uma obra pode ser o

\footnotetext{
${ }^{20}$ A Estação - Revista Ilustrada da Família, 15-04-1888.

${ }^{21}$ SARAIVA, Juracy Assmann. Entre o folhetim e o livro: a exposição da prática artesanal da escrita. In: Machado de Assis ensaios da crítica contemporânea. GUIDIN, M. L., GRANJA, L., RICIERI, F.W. (Orgs.). São Paulo: Editora da Unesp, 2008. p. 199-223. p. 211.
} 
aproveitamento coletivo de estratos culturais diversos sob um mesmo título, esses estratos culturais coletivos, ou diversos, embora trazendo variações em relação a um enredo determinado, podem ser agrupados sob um mesmo título. Como a obra é composta por extratos diversos, a assinatura perde a identidade singularizada e passa a ser coletivizada.

Embora as mudanças ocorridas da primeira para a segunda versão de Quincas Borba sejam muitas e significativas, possibilitando a Saraiva ${ }^{22}$ levantar a hipótese de que "para Machado, a escrita da primeira versão é um exercício em que ele testa os rumos que pretende dar à narrativa, criando em seus leitores expectativas que não desenvolve, como se simulasse o atendimento às convenções romanescas do folhetim para, simultaneamente, romper com elas", a fábula de Quincas Borba se cristaliza na recepção do público como uma história única e não diversificada. É evidente que esse é o processo próprio de recepção de uma sociedade iletrada, acostumada com a circulação de fatias de ficção pela oralidade.

Assim como Ponson du Terrail incorporava as notícias dos jornais faits divers para a composição do seu lendário herói rocambolesco, e embora Machado de Assis afirme nunca ter lido Rocambole, ${ }^{23}$ o que não o impede de ter participado de oitivas durante a infância, o autor fluminense não apenas alimenta seus romances de publicação seriada com o próprio suporte em que veicula sua literatura, como parece ter predileção pelos "fatos diversos", que não podem ser nomeados segundo um catálogo conhecido de referências, numa sociedade aparentemente subordinada à política higienista e progressista dos anos setenta do século XIX.

Essa política inclui determinantes de práxis sociais, divulgadas pelos veículos impressos, como revistas e jornais. Além dos textos escritos, no século XIX "the readers had in their field of vision the continuation of the serialized narrative and other textual and pictorial elements, all bound together by the same editorial principles". ${ }^{24}$ Entre esses elementos, estavam, por exemplo, seções de modas e anúncios que

\footnotetext{
${ }^{22}$ Idem, p. 213-214.

${ }^{23}$ ASSIS, Machado de. Obra Completa, v. 3, p. 356.

24 "[...] os leitores tinham em seu campo de visão a continuação da narrativa serializada e outros elementos textuais e pictóricas, todos unidos pelos mesmos princípios editoriais". (SILVA, Ana Cláudia Suriani da. Machado de Assis's Philosopher or Dog? From serial to book form, cit., p. 3. Tradução livre.)
} 
incentivavam a prática da filantropia. O leitor que lesse Quincas Borba submetia-se não apenas às "Les lois de l'imitation", ${ }^{25}$ mas também à irrisão dessas convenções, à medida que Machado as incorporava no corpo de sua narrativa para evidenciá-las como práticas extemporâneas e fora de lugar no contexto brasileiro. Basta lembrar que a filantropia praticada por Sofia é motivada por um desejo de ascensão social e oriunda de um comportamento condenável que inclui a sedução de Rubião, para explorá-lo e deixá-lo suscetível à exploração do marido Palha.

Kenner $^{26}$ considera que Flaubert seria a matriz dos escritores considerados como "comediantes estoicos", seguido por Joyce e Beckett. Esse termo definiria aqueles escritores que percebem a literatura como um sistema fechado de signos, em que as 26 letras do alfabeto e suas possibilidades comutativas, assim como os lugares adequados dos diversos atos de falas e situações específicas de comunicação, são os recursos que permitem ao escritor a invenção de uma técnica que diferencia as possibilidades da comunicação escrita das práticas de oitiva. No caso de Flaubert, Kenner argumenta que o escritor chegou a organizar um dicionário, denominado "Dicionário de lugares comuns", no qual registrava as várias possibilidades de fala dos personagens em situações específicas de convívio social. O diálogo de Emma Bovary, com um de seus amantes, à beira do mar, que "Sugere grandes pensamentos", ${ }^{27}$ estaria catalogado nesse dicionário. Assim como a opinião proferida sobre música erudita "- Oh! A música alemã, aquela que convida a sonhar!", ${ }^{28}$ em resposta à pergunta de Léon: "- Que música você prefere?". ${ }^{29}$ Se Eça de Queirós propunha a literatura de inventário, como critica Machado de Assis, em texto sobre o Primo Basílio, em 1878, Machado adota a estratégia de Flaubert de estilizar o uso oral da língua, ao denunciá-lo como convenção cultural por meio da escrita.

No capítulo 42 de Quincas Borba, na cena em que Sofia é surpreendida pelo major Siqueira, fitando o cruzeiro do sul, acompanhada de Rubião, o major repete três

\footnotetext{
${ }^{25}$ TARDE, Gabriel. Les lois de l'imitation. Paris: Feliz Alcan, 1895.

26 KENNER, H. Flaubert, Joyce y Beckett. Los comediantes estoicos. México: Fondo de Cultura Económica, 2011.

${ }^{27}$ Idem, p. 42, tradução livre.

${ }^{28}$ Idem, p. 43, tradução livre.

${ }^{29}$ Ibidem.
} 
vezes que "a lua estava deliciosa, era uma lua para namorados" (p. 80), num espaço gráfico de seis linhas (seguindo a primeira edição em livro, de 1891, idêntica ao trecho publicado em folhetim, na edição de 15 de dezembro de 1886). A vulgaridade da fala, com sugestões descorteses de um suposto adultério de Sofia, é subordinada pela sua repetição insistente simetricamente relacionada ao número de linhas em que é formulada. Dessa forma, Machado constrói uma estratégia especular em que configura, de forma radical, duas inversões do uso da linguagem: no plano semântico, o narrador busca definir o atributo como substância do caracterizado por esse atributo, os termos "deliciosa", "para namorados" passam a ser a substância do termo "lua". No plano gráfico, a repetição simétrica dos termos em proporção ao número de linhas evidencia o meio de construção para além daquilo que é expresso. Dessa forma, o discurso escrito, feito para ser visto, subordina o discurso oral da oitiva.

Embora o texto escrito seja idêntico tanto no romance seriado quanto no folhetim, aparece, no romance, uma distinção gráfica que contribui para o efeito de suspense na cena. Em folhetim, o capítulo leva o número 41 e inicia-se no fim da página em que o capítulo 40 foi publicado. Em livro, embora o capítulo anterior à cena (41) termine antes do fim da página, Machado escolhe deixar o espaço branco livre e começar o capítulo 42 no início da página seguinte. Esse procedimento não era padrão, pois, em outras circunstâncias, o editor de Machado aproveita poucas linhas no fim da página para dar início a um capítulo novo, como na página 88, em que o fim da página comporta apenas duas linhas do capítulo 45.

$* * *$

\section{Referências:}

ASSIS, M. Memórias póstumas de Brás Cubas. Rio de Janeiro: Typographia Nacional, 1881.

Quincas Borba. Rio de Janeiro: H. Garnier Livreiro-Editor, 1891.

. Dom Casmurro. Paris, Rio de Janeiro: H. Garnier Livreiro- Editor, 1889.

. Esaú e Jacó. Paris, Rio de Janeiro: H. Garnier Livreiro- Editor, 1904.

. Memorial de Aires. Paris, Rio de Janeiro: H. Garnier Livreiro- Editor, 1908.

. Quincas Borba - Apêndice. Edições Críticas de Obras de Machado de Assis 2. ed. v. 14-A. Rio de Janeiro: Civilização Brasileira, 1977. 
. Empréstimo de ouro. Cartas de Machado de Assis a Mário de Alencar. Org. Introd. e notas: Eduardo F. Coutinho e Teresa Cristina Meireles de Oliviera. Rio de Janeiro: Ouro sobre Azul, 2009.

. Obra completa. Rio de Janeiro: Aguilar, 1962. 3 v.

AUERBACH, E. Figura. Trad. Duda Machado. São Paulo: Ática, 1997.

BAPTISTA, A. B. Autobibliografias - solicitação do livro na ficção e na ficção de Machado de Assis. Lisboa: Relógio D'Água, 1998.

A formação do nome. Duas interrogações sobre Machado de Assis. Campinas: Editora Unicamp, 2003.

BOSI, A. Figuras do narrador machadiano. In: Cadernos de Literatura Brasileira, n. 23/24, jul. 2008, Instituto Moreira Salles, São Paulo.

Cadernos de Literatura Brasileira, n. 23/24, jul 2008, Instituto Moreira Salles, São Paulo.

CALDWELL, H. The Brazilian Othello of Machado de Assis. A Study of Dom Casmurro. Los Angeles: University of California Press, 1960.

CINTRA, I. A. O nariz metafísico ou a retórica machadiana. In: Recortes Machadianos. Org. Ana Salles Mariano e Maria Rosa Duarte de Oliveira. 2. ed. São Paulo: Nankin; Edusp; Educ, 2008. p. 111-130.

FOUCAULT, M. O que é um autor? In: Ditos e Escritos: Estética - literatura e pintura, música e cinema. v. 3. Rio de Janeiro : Forense Universitária, 2001. p. 264-298.

GRANJA, L. Segredos de uma viúva moça: considerações sobre um conto polêmico de Machado de Assis. In: XI Encontro Regional da ABRALIC, 2007, São Paulo. XI Encontro Regional da ABRALIC - cd-rom, 2007.

GENNETTE, G. Paratextos Editoriais. Trad. Álvaro Faleiros. Cotia: Ateliê, 2009.

GUMBRECHT, H. U. Produção de presença: o que o sentido não consegue transmitir. Trad. Ana Isabel Soares. Rio de Janeiro: Contraponto, Ed. Puc-Rio, 2010.

HANSEN, J. A. Autor. In: Palavras da crítica. Org. José Luis Jobim. Rio de Janeiro: Imago, 1992. p. 11-44

. "O imortal" e a verossimilhança. In: Teresa: revista de literatura brasileira, $\mathrm{n}$. 6/7. São Paulo: Ed. 34; Imprensa Oficial, 2006. p. 56-78.

Dom Casmurro: simulacro \& alegoria. In: Machado de Assis ensaios da crítica contemporânea. GUIDIN, M. L., GRANJA, L., RICIERI, F.W., Orgs. São Paulo, Editora UNESP, 2008. p. 143-177.

Anatomia da sátira. In: Permanência Clássica: visões contemporâneas da antiguidade greco-romana. Org. Brunno V. G. Vieira e Márcio Thamos. São Paulo: Escrituras Editora, 2011. p. 145-170.

KENNER, H. Flaubert, Joyce y Beckett. Los comediantes estoicos. México: Fondo de Cultura Económica, 2011.

MOLLIER, J. Y. A leitura e seu público no mundo contemporâneo: ensaios sobre história cultural. Trad. Elisa Nazarian. Belo Horizonte: Autêntica Editora, 2008. 
PASSOS, L. J. Machado de Assis - o romance com pessoas. São Paulo: Edusp; Nankin, 2007.

PEIXOTO, M. Aires as narrator and Aires as character in Essaú e Jacó. Luso-Brazilian Review, v. 17, n. 1, 1980.

RICARDOU, J. Pour une théorie du nouveau roman. Paris: Éditions du Seul, 1971.

SARAIVA, J. A. Entre o folhetim e o livro: a exposição da prática artesanal da escrita. In: Machado de Assis ensaios da crítica contemporânea. GUIDIN, M. L., GRANJA, L., RICIERI, F.W., Orgs. São Paulo: Editora da Unesp, 2008. p. 199-223.

SILVA, A. M. S. Os bárbaros submetidos - Interferências midiáticas na prosa de ficção brasileira. São Paulo: Arte e Ciência; Unimar, 2006.

Figuração, Leituras e Formatividade em Memórias póstumas de Brás Cubas. In: À roda de Memórias póstumas de Brás Cubas: leituras. Org. Maria Celeste Tommasello Ramos, Sérgio Vicente Motta. Campinas: Alínea, 2006. p. 85-105.

SILVA, A. C. S. Machado de Assis's Philosopher or Dog? From serial to book form. Oxford: Legenda (Maney Publishing), 2010.

Dom Casmurro: uma elegia moderna - Diálogo com Lord Jim, de Joseph Conrad. In: SENNA, M. e GUIMARÃES, H. S. (Orgs.). Machado de Assis e o outro: diálogos possíveis. 1. ed. Rio de Janeiro: Móbile Editorial, 2012. p. 139-157.

TARDE, G. Les lois de l'imitation. Paris: Feliz Alcan, 1895.

TEIXEIRA, I. Irônica invenção do mundo - uma leitura de O Alienista. In: Machado de Assis ensaios da crítica contemporânea. GUIDIN, M. L., GRANJA, L., RICIERI, F.W., Orgs. São Paulo, Editora UNESP, 2008, p. 109-142.

Periódicos:

Revista Brazileira

A Estação: Revista Ilustrada da Família.

Daniela Soares Portela é doutora em Letras, pela Unesp, e professora do curso de Comunicação Social da UEMG - Frutal. Desenvolveu projeto de pós-doutorado na USP sobre o tema: "A incorporação das convenções gráficas na prosa romanesca de Machado de Assis". Publicou "A máscara da autoria em Mário de Andrade: teatralização da ficção", e "A construção da ficção: uma leitura performática de Memórias póstumas de Brás Cubas". Atualmente desenvolve projeto de pós-doutorado sobre o experimentalismo estético na obra de Mário de Andrade, na Unicamp com bolsa CNPQ. Email: <soares-portela@uol.com.br>

Recebido: 08.09.2013

Aprovado: 20.11.2013 